\title{
Discussion panel members
}

Leszek Balcerowicz Governor, The National Bank of Poland. Professor of Economics. Former chairman, Council of the Center for Social and Economic Research (CASE). Formerly Poland's Deputy Prime Minister and Minister of Finance.

Daniel Daianu Professor, Academy of Economic Studies in Bucharest, Romania. Former Finance Minister of Romania. Former Chief Economist, National Bank of Romania.

Vaclav Klaus Professor of Economics. President, Chamber of Deputies of the Czech Parliament. Former Prime Minister and Minister of Finance of the Czech Republic.

Jacques de Larosiere International banker, advisor to Paribas. Former President, EBRD. Former Governor, Bank of France. Former Managing Director, IMF.

Gramoz Pashko Professor of Economics at Tirana University, Albania. Chief Economic Advisor to the Prime Minister of Albania. Former Deputy Prime Minister and Minister of the Economy. Former Deputy at the Parliament.

Jeffrey D. Sachs Gallen L. Stone Professor of International Trade and Director of the Center for International Development at Harvard University, Cambridge, MA, USA. 
Lucjan T. Or lowski - 9781843762973 Downloaded from PubFactory at 04/26/2023 01:21:37PM 